\title{
Risk Management of Pile Foundation Work Using Analytical Hierarchy Process Method (AHP)
}

\author{
Alitra $^{1}$, Resmi Bestari ${ }^{2}$ and Bambang Purwoko K.B ${ }^{3}$ \\ ${ }^{1-2}$ Department of Civil Engineering \\ Mercu Buana University, \\ Jakarta, Indonesia \\ ${ }^{3}$ Department of Civil Engineering \\ Bakrie University, \\ Jakarta, Indonesia
}

\begin{abstract}
Risk factors as the cause of the condition are not expected to cause any harm, damage or loss. The measure of risk based on the probability of failure of structural and monetary consequences of failure, and accounts for the material damage from time to time. The purpose of this study was to determine the factors (events that enable the) risk on pile foundation work and determine the weight/risk priority ranking of pile foundation work execution. This study uses analysis Analytical Hierarchy Process (AHP) to obtain risk factors pile foundation dominant conveyor manufacturing building consisting of 21 risk factors (criteria). The risk assessment carried out by 5 (five) Expert. The results in getting the expert assessment of the risk factors pile foundation work of the most dominant is the criterion of cost control systems are a weak and weak time control system.
\end{abstract}

Keywords: Analytical Hierarchy Process, Risk Management, Foundations Piles.

\section{INTRODUCTION}

Industrial development in the business sector coal mining is a government effort to increase foreign exchange and if the terms of the pattern of community life is directly dependent on the increase in goods and services, the use of sources of energy, and natural resources. The use of natural resources massively without neglecting the environment can lead to various negative impacts felt in the short term and in the long term. Adequate equipment will increase the productivity of the company. Belt conveyor is one means of conveyance raw material most widely used in the industry. This tool also has a payload capacity large enough. Applications include conveyor belt transport means in the cement plant, coal, fertilizer plant and stone processing plant aggregates (stone split). This tool can transport bulk material or large chunks (eg, crack stone) up to moderate size (eg coal). PT X is one of the contractor mine in Indonesia which is currently developing the construction manufacturing conveyor. Conveyor construction using structures pile foundation. The foundation piles is one of the elements that serves to move the burden of building structures and building loads to the ground. Generally pile foundation been used or if the soil conditions are relatively stable and hard soil depth is affordable or not lies far below the soil surface. Jobs pile foundation worked land and river, this work certainly has a lot of risk on the workmanship both overland and river channels. In construction projects are characterized as a series of activities that take place in a limited time with a specific allocation of resources to produce products with criteria outlined in the contract document. Therefore at the time of construction, the developer will be burdened by a variety of uncertainties that are consequences risk.

\section{ANALYTIC HIERARCHY PROCESS (AHP)}

This method is used to look at the dominant risk factor. Simply put, there are two main criteria that influence the rank of risk factors, namely the frequency or of opportunity for risk itself. One of the method of decision-making is using Analytic Hierarchy Process (AHP). Another advantage of using AHP is its ability to solve problems and multicriteria multiobjectives [1]. AHP is a decision-making process by using pairwise comparisons (pair wise comparisons) to explain the evaluation factors and weighting factors in multi-factor condition [2]. The method of analysis is essential to identify the variables that are relevant to the research results obtained in accordance with the purpose. As an input to this analysis is the data information on the results of the questionnaire respondents. AHP is a method used to solve complex problems and are not structured into groups, by organizing groups into hierarchies, then enter a numerical value instead of human perception of relative comparison. By the synthesis, it will be able to determine which elements should have the highest priority [3]. 
Table. 1. Scale comparison

\begin{tabular}{|c|c|c|}
\hline $\begin{array}{l}\text { Intensity } \\
\text { Interest }\end{array}$ & Information & Explanation \\
\hline 1 & Both elements are equally important & Two elements have the same effect on goals \\
\hline 3 & $\begin{array}{l}\text { Elements that one bit of importance } \\
\text { than other elements }\end{array}$ & $\begin{array}{l}\text { Experience and judgment slightly favor one element by comparison } \\
\text { with other elements }\end{array}$ \\
\hline 5 & $\begin{array}{l}\text { Elements which one is more } \\
\text { important than other elements }\end{array}$ & $\begin{array}{l}\text { Experience and very strong valuation support one element than } \\
\text { other elements }\end{array}$ \\
\hline 7 & $\begin{array}{l}\text { One obvious element is the absolute } \\
\text { importance of other elements }\end{array}$ & One powerful element supported and looked dominant in practice \\
\hline 9 & $\begin{array}{l}\text { One absolutely essential element } \\
\text { other than the elements }\end{array}$ & $\begin{array}{l}\text { Evidence supporting elements that one has the highest possible } \\
\text { degree of confirmation strengthens compared to other elements. }\end{array}$ \\
\hline $2,4,6,8$ & $\begin{array}{l}\text { The values between these two values } \\
\text { between the two options }\end{array}$ & is given when there are two adjacent consideration compromise \\
\hline
\end{tabular}

\section{FOUNDATION PILES}

Pile foundation is one of the elements that serves to move the burden of building structures and building loads to the ground [4]. Commonly used or been piling if the soil conditions are relatively stable and hard soil depth is affordable or not lies far below the soil surface. In the structure of the building, the foundation serves to carry the burden of existing buildings thereon. To produce a solid construction, the foundation must also be planned and carried out with extreme caution. The foundation must be calculated in such a way in terms of both dimensional and mechanical analytical way.

\section{RISK MANAGEMENT}

The concept of risk on the project as a measure of the probability and the consequences of not reaching a predetermined project objectives [5]. Risk has two main components to the event, which is the probability of occurrence and impact of events that occurred. Project risk can be defined as the cumulative effect of uncertainty resulting opportunities for not achieving the project objectives: cost, time, quality and field of work. Risk factors as the cause of the condition is not expected to cause any harm, damage or loss. Measure of risk based on the probability of failure of structural and monetary consequences of failure, and accounts for the material damage from time to time [6]. The risks must be managed properly so that events can take place as planned. Risk management contracting business can be defined as a combination of art and science anatara in identification, analysis, and response to all risks identified in all areas of business, and in all its stages, to keep the business goals that have been set. Risk management is an organized approach to finding potential risks so as to reduce the occurrence of unexpected things. The first failure probability is estimated by assuming that there is no improvement or rehabilitation is done.

Risk management is committed approach to risk is to understand, identify and evaluate the risks of a project [7]. Then consider what to do about the impact and possible transfer of risk to others or reduce the risk. Risk management is all a series of activities related to the risk of planning (planning), assessment (assessment), handling (handling) and monitoring (monitoring) the risk [8]. The objective of risk management is to identify risks in a project and develop strategies to reduce or even avoid, on the other hand should also be sought ways to maximize the opportunities that exist [9].

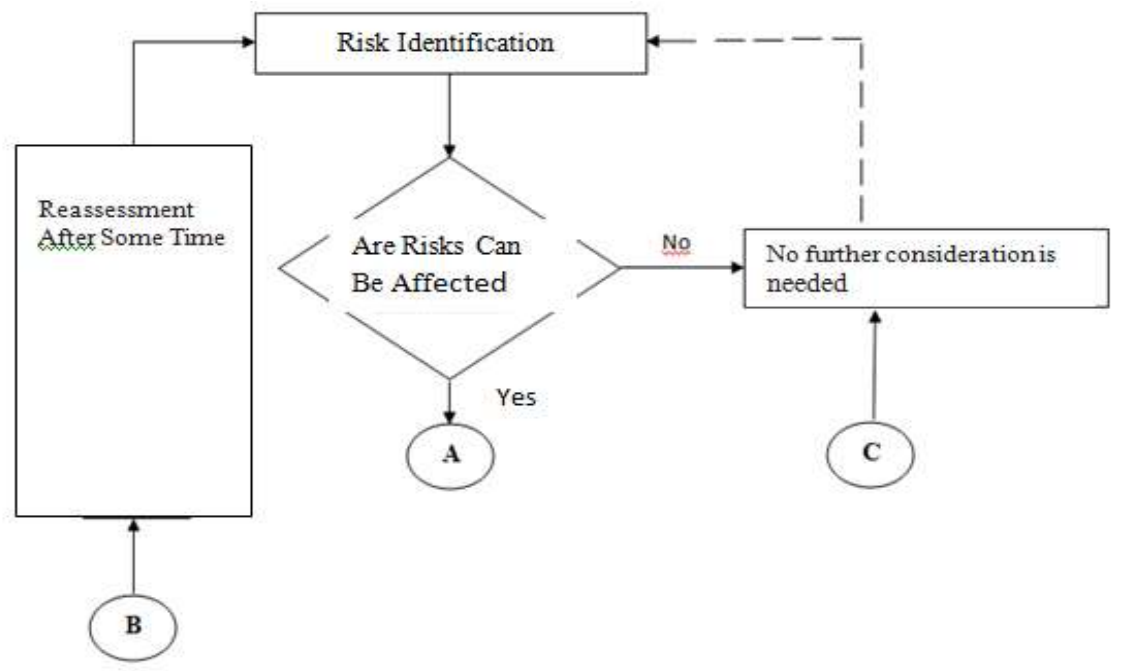

Figure 1. Flowchart of Risk Management 


\section{RESEARCH OBJECTIVES}

The purpose of this study:

a. To determine the factors (events that enable the) risk on pile foundation work.

b. Determining the weight / risk prioritization rankings Piles foundation work execution results of questionnaires from experts with AHP analysis method.

\section{RESEARCHMETHODS}

According to the research method is [10] basically a scientific way to obtain valid data with the aim of discovery, evidence and knowledge development so that the results can be used to understand, solve and anticipate problems. Flow in this study are:

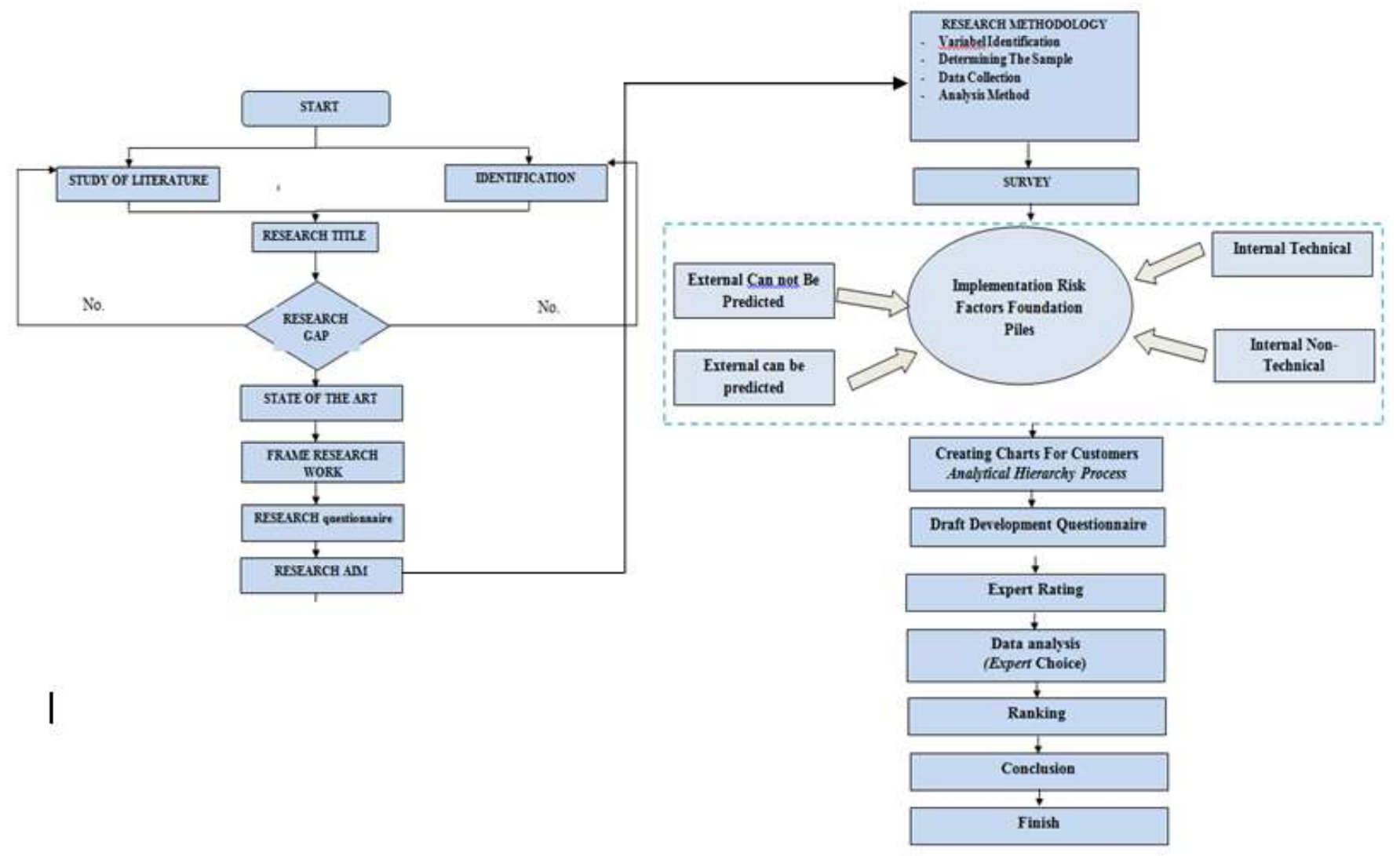

Figure 2. Flow Research

\section{IDENTIFICATION OF VARIABLES}

Research variables include factors that play a role in the event or phenomenon to be studied, in the implementation, pile foundation work include:

Table. 2 Variable Research

\begin{tabular}{|c|c|c|}
\hline variables & Risk categories & Sub Risk Factors \\
\hline \multirow{14}{*}{ 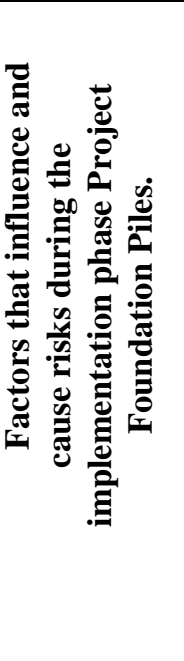 } & \multirow{9}{*}{$\begin{array}{c}\text { Internal Non- } \\
\text { Technical }\end{array}$} & Cost \\
\hline & & Weak Cost Control System \\
\hline & & Added costs \\
\hline & & The existence of unrecognized work is paid \\
\hline & & $\begin{array}{l}\text { Scheduling } \\
\end{array}$ \\
\hline & & Time control weak \\
\hline & & Other work that precedes late \\
\hline & & Preparation of the series of jobs (sequecing) unfavorable. \\
\hline & & Tight project schedule \\
\hline & \multirow{5}{*}{$\begin{array}{l}\text { Internal } \\
\text { Technical }\end{array}$} & Land Cleanup \\
\hline & & Work access \\
\hline & & Late arrival Materials \\
\hline & & Difficult field conditions \\
\hline & & The number of project implementers less \\
\hline
\end{tabular}


International Journal of Engineering Research And Advanced Technology, Vol.5, Issue 5, May-2019

\begin{tabular}{|c|c|c|}
\hline Variables & $\begin{array}{c}\text { Risk } \\
\text { Categories }\end{array}$ & Sub Risk Factors \\
\hline \multirow{12}{*}{ 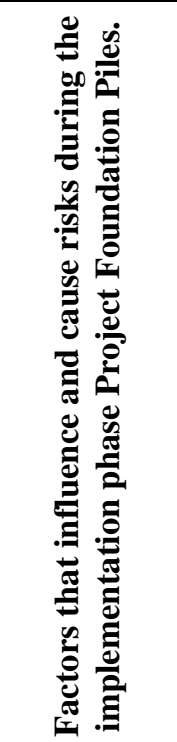 } & \multirow{12}{*}{$\begin{array}{l}\text { Internal } \\
\text { Technical }\end{array}$} & Surveying \\
\hline & & Coordinate measurement error \\
\hline & & Error determining the point of foundation \\
\hline & & Data processing error measurement \\
\hline & & Misrepresent the survey results \\
\hline & & Settings and Placement Tools \\
\hline & & Delay booking tool \\
\hline & & Heavy equipment placement errors \\
\hline & & Low productivity tool \\
\hline & & Damage tool \\
\hline & & When require cuts in its implementation will be difficult and take a long time \\
\hline & & Age tools are not feasible \\
\hline
\end{tabular}

\section{CONSISTENCY TEST}

The use of AHP in the process analisinya use human perception as input, therefore the inconsistency is very possible because humans have limitations in expressing his perception consistently, especially if have to compare many criteria. Based on this condition, people can declare that perception will be consistent or not. Consistency measurement is intended to inconsistencies response given by the respondent. If $\mathrm{CR}<0.1$ then the value of pairwise comparison matrices given criteria consistent. If $\mathrm{CR}>0.1$ then the value of the pairwise comparison matrix given inconsistent criteria. So if it is not consistent, then filling the values of matrix elements in pairs on the criteria and alternatives should be repeated.

\section{RESULT GLOBAL PRIORITY (EXPERT 1)}

After each of the criteria, sub-criteria have been obtained then the next step is to do an alternative synthesis to obtain overall weighting of criteria. Previous weight / local priority (local priority) to look for the value of its global (global priority) beforehand. Overall global weight value can be seen in Figure 3. From the data that has been calculated above showed that overall. Weak cost control system with weight value 0.335 is the first priority to the risk of pile foundation work. The second priority is a time control weak with weight value 0.137 , while the last priority is if require cuts in the implementation will be difficult and take a long time with the weight value of 0.003 .

\begin{tabular}{|c|c|}
\hline $\begin{array}{r}\text { Expert } 1 \\
\text { Risk Factors Work Fo }\end{array}$ & $\begin{array}{l}\text { nstance -- Synthesis with respect to: } \\
\text { ndation Piles On Conveyor Manufacturing Building } \\
\text { Overall Inconsistency }=.07\end{array}$ \\
\hline Weak cost control system & .335 \\
\hline Time control weak & .137 \\
\hline The existence of unrecognized work is paid & .105 \\
\hline Difficult field conditions & .081 \\
\hline Late arrival of materials & .049 \\
\hline Added costs & .044 \\
\hline Error determining the point of foundation & .044 \\
\hline Preparation of a series of jobs (sequecing] poor & .034 \\
\hline Delay booking tool & .030 \\
\hline The number of project officers with less & .023 \\
\hline Tight project schedule & .022 \\
\hline Coordinate measurement error & .019 \\
\hline Low productivity tool & .018 \\
\hline Damage tool & .014 \\
\hline Access to jobs & .011 \\
\hline Error drawing survey results & $.008 \square$ \\
\hline Land clearing & $.007 \square$ \\
\hline Age tools are not feasible & $.007 \square$ \\
\hline Error processing measurement data & $.006 \square$ \\
\hline Heavy equipment placement errors & .003 \\
\hline When require cuts in the implementation will be difficult and take a long time & $.003 \square$ \\
\hline
\end{tabular}

Figure 3. Priority of importance (weights) risk criteria in the implementation of the foundation Piles Source: Data processing by Expert Choice 


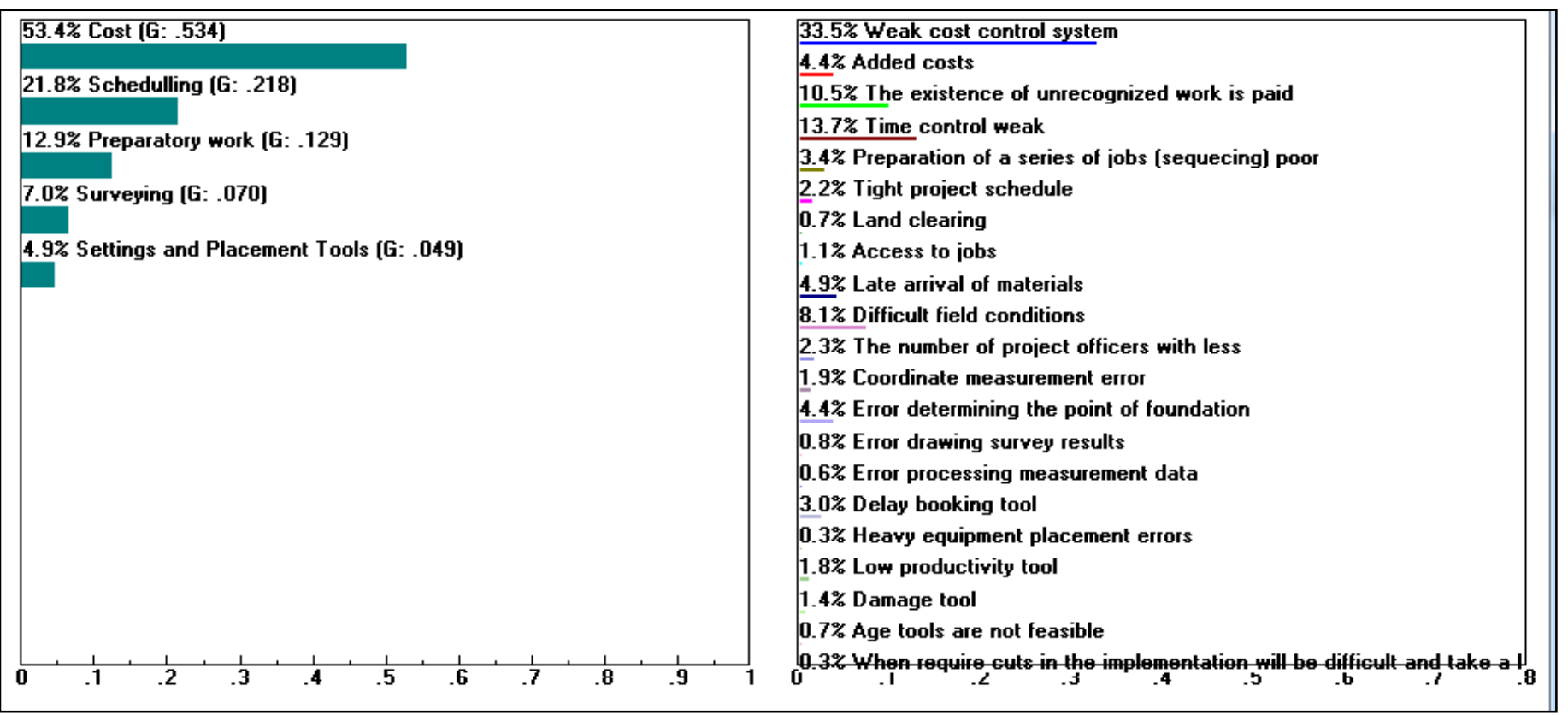

Figure 4. Dynamic Sensitivity

Source: Data processing by Expert Choice

\section{RESULT GLOBAL PRIORITY (EXPERT 2)}

After each of the criteria, sub-criteria have been obtained then the next step is to do an alternative synthesis to obtain overall weighting of criteria. Previous weight / local priority (local priority) to look for the value of its global (global priority) beforehand. Overall global weight value can be seen in Figure 5. From the data that has been calculated above showed that overall. The system is weak cost control with weight value 0.329 is the first priority to the risk of pile foundation work. The second priority is time control weak with weight value 0.123 , while the last priority is the need cuts in its implementation will be difficult and take a long time with the weight value of 0.004 .

\begin{tabular}{|c|c|}
\hline $\begin{array}{r}\text { Expert } 2 \\
\text { Risk Factors Work Fo }\end{array}$ & $\begin{array}{l}\text { instance }- \text { Synthesis with respect to: } \\
\text { andation Piles On Conveyor Manufacturing Building } \\
\text { Overall Inconsistency =.08 }\end{array}$ \\
\hline Weak cost control system & .329 \\
\hline Time control weak & .123 \\
\hline Added costs & .096 \\
\hline The number of project officers with less & .078 \\
\hline The existence of unrecognized work is paid & .056 \\
\hline Difficult field conditions & .044 \\
\hline Coordinate measurement error & .044 \\
\hline Preparation of a series of jobs (sequecing) poor & .041 \\
\hline Delay booking tool & .030 \\
\hline Late arrival of materials & .026 \\
\hline Error determining the point of foundation & .025 \\
\hline Heavy equipment placement errors & .022 \\
\hline Tight project schedule & .018 \\
\hline Low productivity tool & .014 \\
\hline Error drawing survey results & .013 \\
\hline Error processing measurement data & .009 \\
\hline Land clearing & $.008=$ \\
\hline Damage tool & $.008 \overline{\mathbf{a}}$ \\
\hline Access to jobs & $.007 \mathbf{0}$ \\
\hline Age tools are not feasible & $.005 \overline{\mathbf{0}}$ \\
\hline When require cuts in the implementation will be difficult and take a long time & .004 ل \\
\hline
\end{tabular}

Figure 5. Priority of importance (weights) risk criteria in the implementation of the foundation Piles Source: Data processing by Expert Choice 


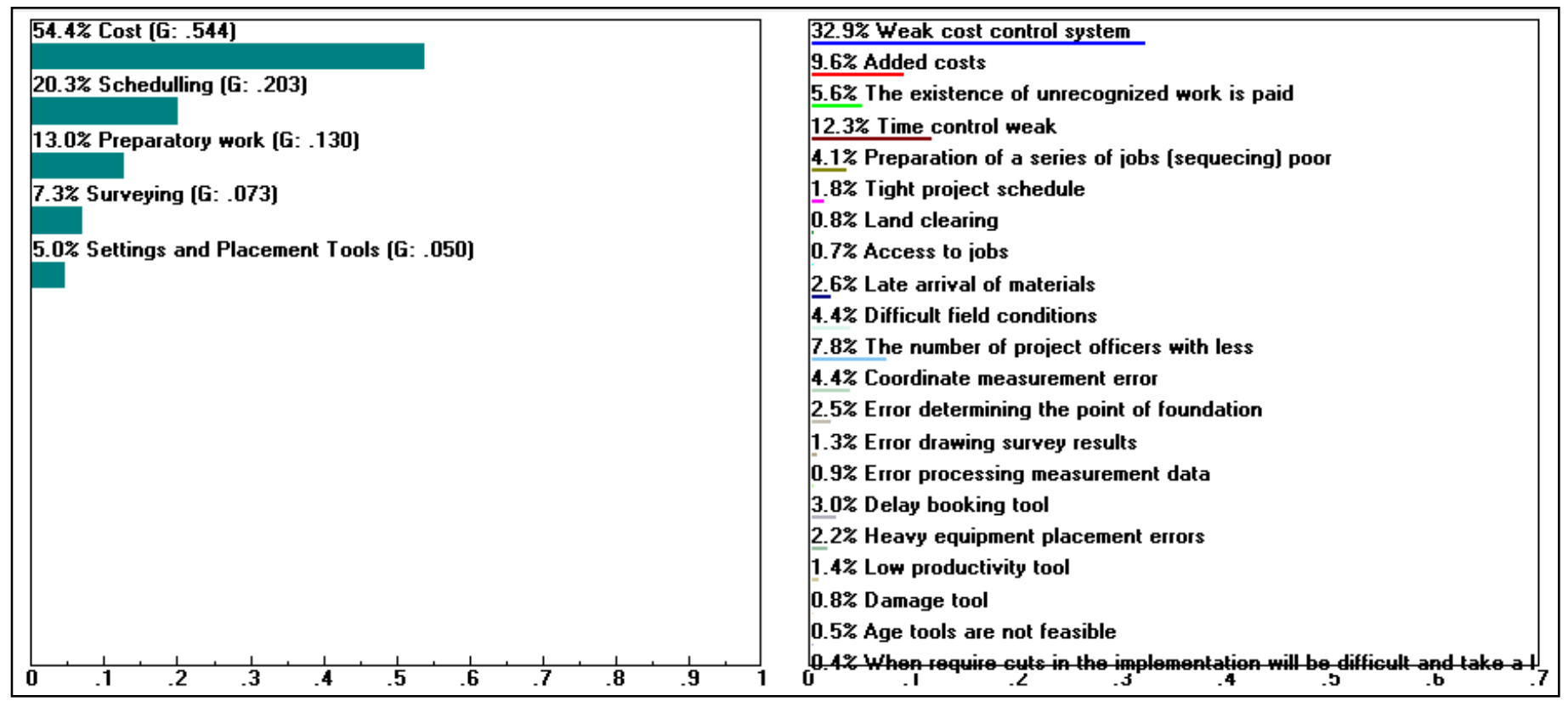

Figure 6. Dynamic Sensitivity

Source: Data processing by Expert Choice

\section{RESULT GLOBAL PRIORITY (EXPERT 3)}

After each of these criteria, the criteria have been obtained then the next step is to do an alternative synthesis to obtain overall weighting of criteria. Previous weight / local priority (local priority), to look for the value of its global (global priority) beforehand. Overall global weight value can be seen in Figure 7. From the data that has been calculated above showed that overall. The system is weak cost control with weight value 0.329 is the first priority to the risk of pile foundation work. The second priority is time control weak with a weight of 0.129 , while the last priority is to delay booking tool with the weight value of 0.004 .

\begin{tabular}{|c|c|}
\hline $\begin{array}{r}\text { Expert } 3 \\
\text { Risk Factors Work Fo }\end{array}$ & $\begin{array}{l}\text { nstance } * \text { Synthesis with respect to: } \\
\text { ndation Piles On Conveyor Manufacturing Building } \\
\text { Overall Inconsistency }=.08\end{array}$ \\
\hline Weak cost control system & .329 \\
\hline Time control weak & .129 \\
\hline Added costs & .103 \\
\hline Difficult field conditions & .059 \\
\hline Coordinate measurement error & .044 \\
\hline The existence of unrecognized work is paid & .043 \\
\hline Preparation of a series of jobs (sequecing) poor & .043 \\
\hline Late arrival of materials & .041 \\
\hline When require cuts in the implementation will be difficult and take a long time & .032 \\
\hline The number of project officers with less & .031 \\
\hline Error determining the point of foundation & .026 \\
\hline Age tools are not feasible & .022 \\
\hline Tight project schedule & .019 \\
\hline Access to jobs & .016 \\
\hline Error drawing survey results & .014 \\
\hline Land clearing & .012 \\
\hline Damage tool & .012 \\
\hline Heavy equipment placement errors & .007 \\
\hline Error processing measurement data & $.006 \overline{-}$ \\
\hline Low productivity tool & $.006 \square$ \\
\hline Delay booking tool & $.004 \overline{\mathbf{I}}$ \\
\hline
\end{tabular}

Figure 7. Priority of importance (weights) risk criteria in the implementation of the foundation Piles Source: Data processing by Expert Choice 


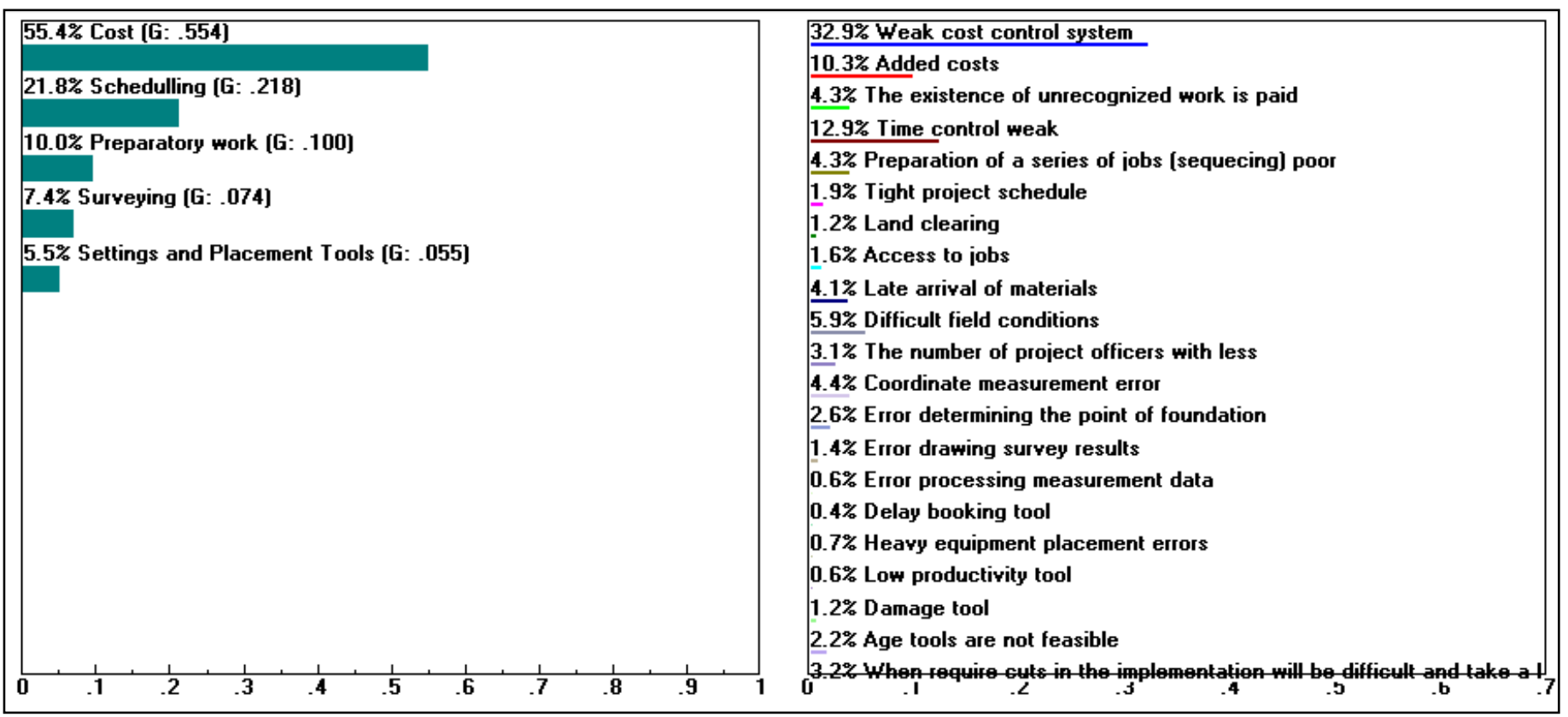

Figure 8. Dynamic Sensitivity

Source: Data processing by Expert Choice

\section{RESULT (EXPERT 4)}

After each criteria, sub-criteria have been obtained then the next step is to do an alternative synthesis to obtain overall weighting of criteria. Previous weight / local priority (local priority), to look for the value of its global (global priority) beforehand. Overall global weight value can be seen in Figure 9. From the data that has been calculated above showed that overall. The system is weak cost control with weight value 0.343 is the first priority for occupational risk pile foundation. The second priority is a time control weak with weight value 0.095 , while the last priority is to delay booking tool with the weight value of 0.003 .

\begin{tabular}{|c|c|}
\hline $\begin{array}{r}\text { Expert } 4 \mathrm{i} \\
\text { Risk Factors Work Fou }\end{array}$ & $\begin{array}{l}\text { nstance }- \text { Synthesis with respect to: } \\
\text { indation Piles On Conveyor Manufacturing Building } \\
\text { Overall Inconsistency = .09 }\end{array}$ \\
\hline Weak cost control system & .343 \\
\hline Time control weak & .095 \\
\hline Added costs & .093 \\
\hline The number of project officers with less & .084 \\
\hline The existence of unrecognized work is paid & .063 \\
\hline Difficult field conditions & .047 \\
\hline Error determining the point of foundation & .042 \\
\hline Late arrival of materials & .033 \\
\hline Preparation of a series of jobs (sequecing) poor & .032 \\
\hline When require cuts in the implementation will be difficult and take a long time & .029 \\
\hline Error drawing survey results & .021 \\
\hline Age tools are not feasible & .017 \\
\hline Access to jobs & .016 \\
\hline Land clearing & .015 \\
\hline Coordinate measurement error & .015 \\
\hline Tight project schedule & .014 \\
\hline Damage tool & .014 \\
\hline Error processing measurement data & .008 \\
\hline Low productivity tool & .008 \\
\hline Heavy equipment placement errors & $.006 \square$ \\
\hline Delay booking tool & $.003 \mathrm{I}$ \\
\hline
\end{tabular}

Figure 9. Priority of importance (weights) risk criteria in the implementation of the foundation Piles Source: Data processing by Expert Choice 


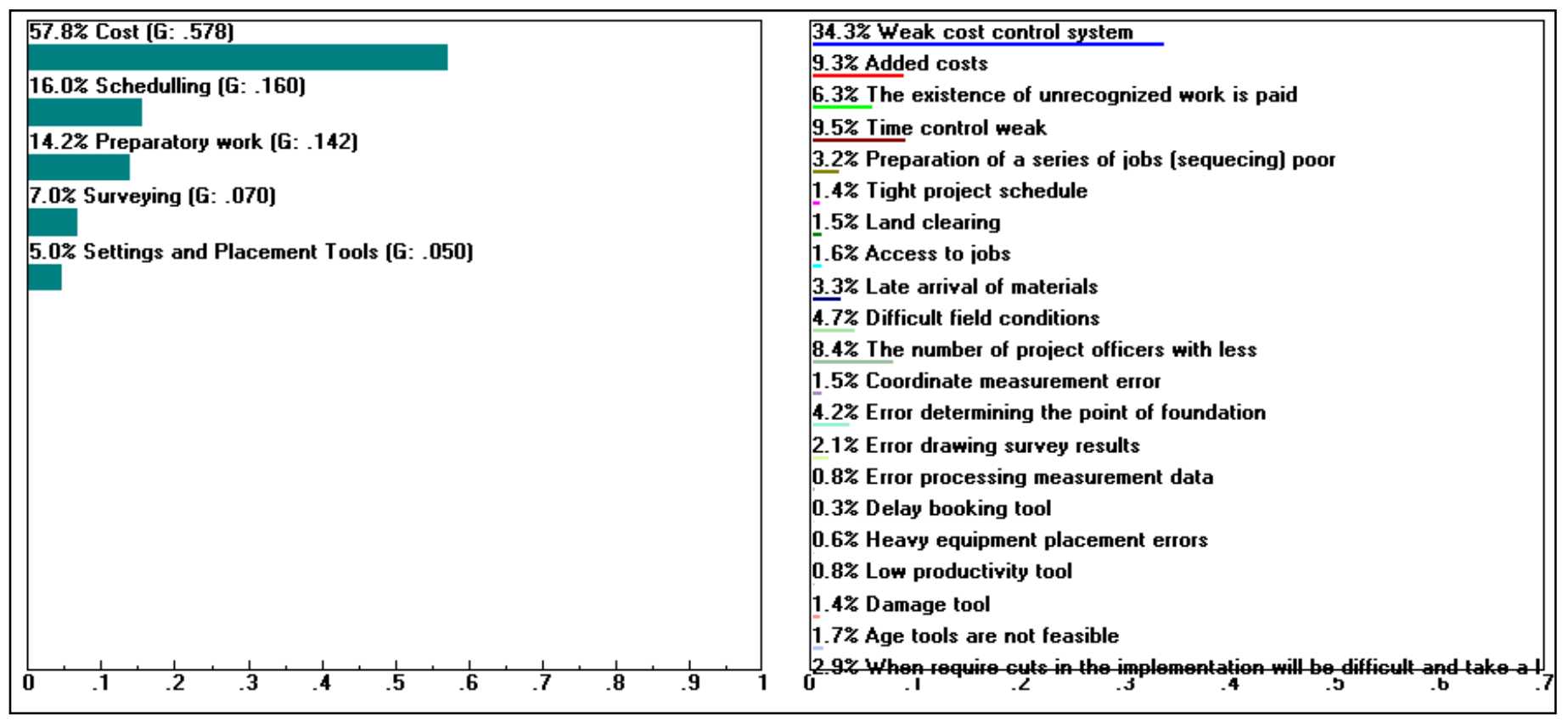

Figure 10. Dynamic Sensitivity

Source: Data processing by Expert Choice

\section{RESULT GLOBAL PRIORITY (EXPERT 5)}

After each of the criteria, sub-criteria have been obtained then the next step is to do an alternative synthesis to obtain overall weighting of criteria. Previous weight / local priority (local priority), to look for the value of its global (global priority) beforehand. Overall global weight value can be seen in Figure 12. From the data that has been calculated above showed that overall. Weak cost control system with weight value 0.287 is the first priority to the risk of pile foundation work. The second priority is a time control weak with weight value 0.116 , while the last priority is if require cuts in its implementation will be difficult and take a long time with the weight value of 0.004 .

\begin{tabular}{|c|c|}
\hline $\begin{array}{r}\text { Expert } 5 \\
\text { Risk Factors Work Fou }\end{array}$ & $\begin{array}{l}\text { stance -- Synthesis with respect to: } \\
\text { ndation Piles On Conveyor Manufacturing Building } \\
\text { Overall Inconsistency }=.07\end{array}$ \\
\hline Weak cost control system & 287 \\
\hline Time control weak & .116 \\
\hline Added costs & 096 \\
\hline Access to jobs & .089 \\
\hline Late arrival of materials & .066 \\
\hline Coordinate measurement error & .044 \\
\hline The existence of unrecognized work is paid & .043 \\
\hline Preparation of a series of jobs (sequecing) poor & .039 \\
\hline Difficult field conditions & 032 \\
\hline Delay booking tool & .032 \\
\hline Error determining the point of foundation & 024 \\
\hline The number of project officers with less & 022 \\
\hline Heavy equipment placement errors & 018 \\
\hline Tight project schedule & 017 \\
\hline Land clearing & .016 \\
\hline Low productivity tool & .016 \\
\hline Error drawing survey results & .013 \\
\hline Damage tool & 011 \\
\hline Error processing measurement data & $.006 \square$ \\
\hline Age tools are not feasible & $.006 \square$ \\
\hline When require cuts in the implementation will be difficult and take a long time & $.004 \mathbf{~ I ~}$ \\
\hline
\end{tabular}

Figure 11. Priority of importance (weights) risk criteria in the implementation of the foundation Piles Source: Data processing by Expert Choice 


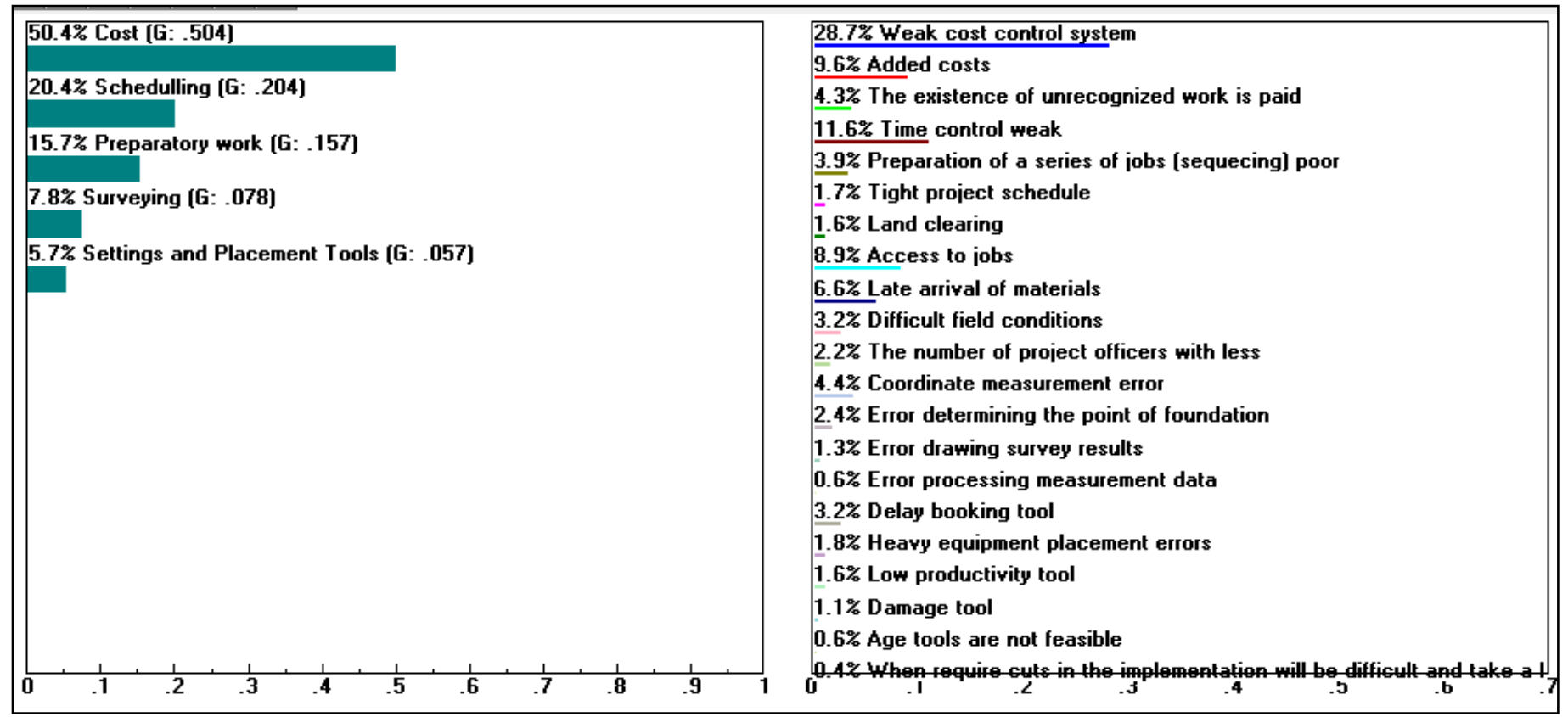

Figure 12. Dynamic Sensitivity

Source: Data processing by Expert Choice

\section{CONCLUSIONS}

Based on the research objectives and the above results it can be concluded that the assessment of the experts (Expert) risk factors pile foundation work on a conveyor manufacturing building consisting of 21 risk factors (criteria). According to experts, one (1) the risk factors of weak cost control system of the most dominant place that is with a weight percentage of $33.5 \%$, the second is a weak time control with a weight of $13.7 \%$ and the lowest is the risk that requires cutting into execution it will be difficult and take a long time with a weighting of $0.3 \%$. According to experts, two (2), the most dominant two risks that occur are weak cost control systems with a weight of $32.9 \%$, while the second is a weak time control system with a weight of $12.3 \%$ and the lower most is the risk that requires cuts in its implementation it will be difficult and requires a long time with a weighting of $0.4 \%$. The assessment of the experts three (3) most dominant risk factors that occur are weak cost control system with a weight of $32.9 \%$, while the second is a weak control system is by weight $12.9 \%$, and the lower most is a risk factor for delay booking tool that is with a weight of $0.4 \%$. According to experts, four (4) The most dominant risk factor occurs is weak cost control system with a weight of $34.3 \%$, while the second is a weak time control system with a weight that is $9.5 \%$, and the lower most is the delay booking tool that is $0.3 \%$. Assessment of experts 5 (five) of the most dominant risk factor occurs is weak cost control with a weight of $28.7 \%$, the second is the risk of a weak time control with a weight of $11.6 \%$, and the lowest is in its implementation if it requires cutting will be difficult and take a long time with a weighting of $0.4 \%$. Based on the assessment of experts on risk factors pile foundation work on a conveyor manufacturing building risk that often happens is that a weak cost control system and risk control systems are weak time.

\section{REFERANCES}

[1] Faroby, Falatehan. (2016). Analytical Hierarchy Process (AHP). Indomedia Library; Yogyakarta.

[2] Zhou Hong-bo, Et al. (2017). AHP-ANP-Fuzzy Integral Integrated Network for Evaluating the Performance of Innovative Business Models for Sustainable Building.

[3] Santoso, D., \& Besral, A. M. (2018). Supplier Performance Assessment Using Analytical Hierarchy Process Method. Sinergi, 22(1), 37. https://doi.org/10.22441/sinergi.2018.1.007

[4] Nurdiani, Nina. (2013). Piles Piling Works: How Piling, Constraints and New Technology. Comtech Vol.4

[5] Kerzner, H. (2001). Project Management. Seventh Edition. John Wiley \& Sons, Inc. New York.

[6] HoumanGhalibafian, et al. (2016). A Risk-Based Approach for Structural Assessment of Port Metro Vancouver's Asset Management.

[7] Labombang. (2011). Risk Management In Construction Project, SMARTekJournal ,.

[8] Kerzner, H. 2001. Project Management. Seventh Edition. John Wiley \& Sons, Inc. New York. 
[9] Wideman, Max.R.(1992). Project and Program Risk Management: A Guide To Managing Project Risk Opportunities. Project Management Institute. America.

[10] Hardjomuljadi, S. (2014). Factor analysis on causal of construction claims and disputes in Indonesia (with reference to the construction of hydroelectric power project in Indonesia). International Journal of Applied Engineering Research, 9(22), 12421-12446. 